Lukasz Kozar $^{1}$

Uniwersytet Łódzki

\title{
Sektor energetyczny, a wyzwania zrównoważonego rozwoju - analiza przestrzennego zróżnicowania sytuacji w UE w oparciu o wybrane wskaźniki ${ }^{2}$
}

\section{Energy Sector and the Challenges of Sustainable Development - Analysis of Spatial Differentiation of the Situation in the EU Based on Selected Indicators}

\begin{abstract}
Synopsis. W artykule przedstawiono wybrane kwestie aktualnie poruszane w zakresie zrównoważonego rozwoju w Unii Europejskiej, a związane jednocześnie z sektorem energetycznym. Stą też została omówiona problematyka zasobooszczedności oraz efektywności energetycznej, produkcji energii z odnawialnych źródeł, czy też wykluczenia społecznego wywołanego brakiem dostępności do źródeł energii po przystępnej cenie. Poza analizą literatury przedmiotu został przedstawiony ranking krajów Unii Europejskiej (UE-28) pod względem poziomu rozwoju sektora energetycznego w kontekście problematyki zrównoważonego rozwoju. W tym celu przeprowadzono wielowymiarowa analize porównawcza przy użyciu wybranych $\mathrm{w}$ toku analizy teoretycznej 8 wskaźników dotyczących aspektów społecznych, gospodarczych i środowiskowych związanych z rozwojem sektora energetycznego. Zakres czasowy analizy obejmował 2016 r. (dostępność danych). Źródłem wartości przyjętych zmiennych był Eurostat. Przeprowadzone analizy wykazały, iż najlepsza sytuacją w zakresie sektora energetycznego na tle ogółu przebadanych państw cechowała się Dania.
\end{abstract}

Słowa kluczowe: zrównoważony rozwój, odnawialne źródła energii, sektor energetyczny, efektywność energetyczna

\begin{abstract}
The article presents selected issues currently discussed in the field of sustainable development in the European Union, and related at the same time to the energy sector. Therefore, the issues of resource efficiency and energy efficiency, energy production from renewable sources, or social exclusion caused by the lack of access to affordable energy sources were discussed. In addition to the analysis of the literature on the subject, the ranking of the European Union countries (EU-28) in terms of the level of development of the energy sector in the context of sustainable development was presented. For this purpose, a multidimensional comparative analysis was carried out using 8 indicators selected in the course of theoretical analysis concerning social, economic and environmental aspects related to the development of the energy sector. The time scope of the analysis covered 2016 (data availability). The source of values of the adopted variables was Eurostat. The analyzes carried out showed that the best situation in the energy sector compared to all of the countries surveyed was characterized by Denmark.
\end{abstract}

Key words: sustainable development, renewable energy sources, energy sector, energy efficiency

JEL Classification: Q01, Q20, Q32, Q41, Q56

${ }^{1}$ mgr, Katedra Pracy i Polityki Społecznej, Instytut Ekonomik Stosowanych i Informatyki,

Wydział Ekonomiczno-Socjologiczny, ul. Rewolucji 1905 r. nr 37, 90-214 Łódź, e-mail: kozarlukasz@gmail.com, https://orcid.org/0000-0002-8426-8471.

${ }^{2}$ Publikacja powstała w ramach dotacji ze środków na badania własne młodych naukowców i uczestników studiów doktoranckich - kod projektu B1811200001938.02. 


\section{Wprowadzenie}

Wraz z rozwojem społeczno-gospodarczym badacze przedmiotu coraz większą wagę przywiązują do problematyki jakości życia. Kwestia ta może być postrzegana przez pryzmat różnych aspektów zarówno społecznych, gospodarczych, jak i środowiskowych (Kryk 2013; Pająk, Dahlke, Kvilinskyi, 2016). W tak wielowymiarowym aspekcie wspomniana koncepcja wprost nawiązuje do idei zrównoważonego rozwoju, gdzie istotnym wyzwaniem staje się zapewnienie rozwoju przyszłym pokoleniom na poziomie co najmniej tożsamym z obecnym (ONZ 1987). Stąd też omawiając problematykę jakości życia oprócz klasycznych czynników jakimi są poziom przestępczości, konsumpcji, zarobków, czy też dostęp do edukacji i służby zdrowia coraz częściej porusza się kwestie związane $\mathrm{z}$ różnymi aspektami środowiskowymi funkcjonowania człowieka w otoczeniu. Wśród nich istotne miejsce zajmuje tematyka związana z oddziaływaniem środowiskowym działalności przedsiębiorstw oraz całych sektorów gospodarki na ich otoczenie (Belz, Binder, 2017; Dyllick, Muff, 2016).

Przywiązywanie coraz większego znaczenia do problematyki środowiskowej obserwować można na podstawie kreowanej przez Komisję Europejską za pomocą strategii (horyzontalnych, środowiskowych oraz sektorowych) wspólnej polityki gospodarczej (SRU 2012; Davies 2017). Istotną rolę w tym aspekcie odgrywa Strategia Europa 2020, w której to zdefiniowano ogólnounijne cele rozwojowe na obecne dziesięciolecie (Europa 2020.., 2010). Wśród nich znajdują się wyzwania środowiskowe ściśle powiązane $\mathrm{z}$ celami społecznymi oraz gospodarczymi, a ukierunkowane na wzrost zasobooszczędności oraz spadek emisji gazów cieplarnianych. W dokumencie tym jednocześnie podkreśla się, iż dotychczasowy sposób gospodarowania nie sprawdził się, co też przyczynia się do konieczności wypracowania nowego modelu gospodarczego, który powinien charakteryzować się większą troską o środowisko naturalne. W literaturze przedmiotu taki sposób gospodarowania nazywa się zieloną gospodarką (Loiseau i in., 2016; McAfee, 2016). Wskazany model cechuje się:

- dążeniem do zmniejszenia zużycia energii poprzez wzrost wydajności produkcji oraz poprawę efektywności energetycznej,

- dywersyfikacją źródeł pochodzenia energii z ukierunkowaniem na osiągnięcie stanu samowystarczalności,

- $\quad$ zapewnieniem konsumentom po przystępnej cenie swobodnego dostępu do źródeł energii.

Przytoczony kierunek rozwoju poza poprawą jakości życia społeczeństw ma przyczynić się do pobudzenia działań ukierunkowanych na innowacyjność oraz tworzenie nowych miejsc pracy. Oba ze wskazanych aspektów mają być wynikiem przede wszystkim wypracowywania nowych, mniej emisyjnych technologii w sektorze energetycznym. Badacze przedmiotu podkreślają przy tym, iż równocześnie należy kłaść nacisk na odpowiedni rozwój technologiczny zarówno energetyki konwencjonalnej, jak i sektora energetyki odnawialnej oraz tworzyć systemy energetyczne, które zapewniałyby bardziej efektywne wykorzystanie energii (Gasparatos i in., 2017; Omer, 2017; Sulich, Zema, 2018).

Zmiany jakie zachodzą w sektorze energetycznym już obecnie stopniowo przyczyniają się do dywersyfikacji źródeł pozyskiwania energii, co też dalej będzie szerzej poruszone na przykładzie UE. Niemniej jednak wraz z rozwojem konceptualnym idei zrównoważonego rozwoju poza klasycznym rozumieniem problematyki związanej z sektorem energetycznym przez pryzmat emisji gazów cieplarnianych, czy też produkcji energii ze źródeł 
odnawialnych, coraz częściej porusza się aspekty społeczne funkcjonowania omawianego sektora gospodarki oraz konieczność zapewnienia bezpieczeństwa energetycznego dla obecnych oraz przyszłych pokoleń (istotny czynnik mogący mieć wpływ na kształtowanie jakości życia) (Pultowicz, 2009; Świerszcz, Grenda, 2018). Stąd też głównym celem niniejszego opracowania jest przedstawienie rankingu krajów UE-28, który pozwala na analizę przestrzennego zróżnicowania sytuacji w zakresie rozwoju sektora energetycznego w poszczególnych krajach UE. Rozważania związane z rozwojem wskazanego sektora będa poruszane wyłącznie w kontekście koncepcji zrównoważonego rozwoju. $Z$ tego też powodu sporządzony wykaz za pomocą wielowymiarowej analizy porównawczej w oparciu o metodę wzorca rozwoju Z. Hellwiga pozwoli na wskazanie państw, do których na obecnym poziomie rozwoju należałoby kierować w pierwszej kolejności pomoc ukierunkowaną na zrównoważony rozwój sektora energetycznego. W państwach cechujących się najniższym poziomem rozwoju na tle ogółu, zdaniem autora, będzie zachodziło ryzyko wystąpienia wielowymiarowego zjawiska wykluczenia energetycznego ludności.

\section{Materiał i metodyka badań}

Istotnym wyzwaniem dla decydentów mających wpływ na kreowanie polityki gospodarczej w poszczególnych państwach jest zapewnienie bezpieczeństwa energetycznego (sytuacji, w której produkcja energii oraz jej dystrybucja nie będę zakłócone). Aby osiagnąć taką sytuację niezbędne staje się zagwarantowanie synergii między podsystemami sektora energetycznego, jakimi są wydobycie, przesył surowców oraz przetwórstwo i dystrybucja energii. Wyzwaniu temu towarzyszy ograniczony dostęp do surowców energetycznych. Chodzi tutaj zarówno o przestrzenne zróżnicowanie występowania konwencjonalnych surowców energetycznych, jak i możliwość pozyskiwania na danym obszarze w sposób efektywny (tudzież opłacalny ekonomicznie) energii wykorzystując jej odnawialne źródła.

Rozwój sektora energetycznego w obszarze odnawialnych źródeł energii postrzegać można $\mathrm{w}$ dwojaki sposób. Z jednej strony stanowi alternatywę dla zapewnienia ciagłości dostaw energii wobec wyczerpujących się surowców konwencjonalnych. Z drugiej zaś strony można upatrywać $\mathrm{w}$ nim szansy na stopniową budowę nowego sposobu gospodarowania jakim jest wspomniana już zielona gospodarka. W takim ujęciu sektor ten będzie stanowił istotny element wdrażania idei zrównoważonego rozwoju $\mathrm{w}$ procesy gospodarcze. Niemniej jednak część spośród badaczy przedmiotu podkreśla, iż obecny sposób pozyskiwania energii ze źródeł odnawialnych może negatywnie wpływać na stan i jakość środowiska przyrodniczego (Gielnik, Rosicki 2013; Zabłocki 2013). W swoich rozważaniach osoby te wówczas poruszają kwestie związane z:

- zużyciem wody w procesie produkcji energii ze źródeł odnawialnych,

- niezrównoważonym procesem produkcji urządzeń do wytwarzania energii z odnawialnych źródeł,

- ubocznymi skutkami towarzyszącymi procesowi produkcji ze źródeł odnawialnych (hałas wywołany działaniem urządzeń, degradacja krajobrazu).

Powyższe dylematy związane z zakwalifikowaniem sektora energetyki odnawialnej do obszarów związanych ze zrównoważonym rozwojem autor niniejszego artykułu w pełni rozumie. Jednakże dla celów przeprowadzanego wywodu zostaje przyjęte za Komisją 
Europejską, iż wzrost udziału energii ze źródeł odnawialnych w końcowym zużyciu energii brutto stanowi wyznacznik zmian $\mathrm{w}$ sektorze energetycznym ukierunkowanych na wdrażanie w procesy gospodarcze idei zrównoważonego rozwoju (tabela 1).

Tabela 1. Udział energii ze źródeł odnawialnych w końcowym zużyciu energii brutto [\%] w państwach UE-28 w 2010 r. oraz 2016 r., a wyznaczony cel związany ze Strategią Europa 2020

Table 1. Share of energy from renewable sources in final gross energy consumption [\%] in the EU-28 in 2010 and 2016 and the set target related to the Europe 2020 Strategy

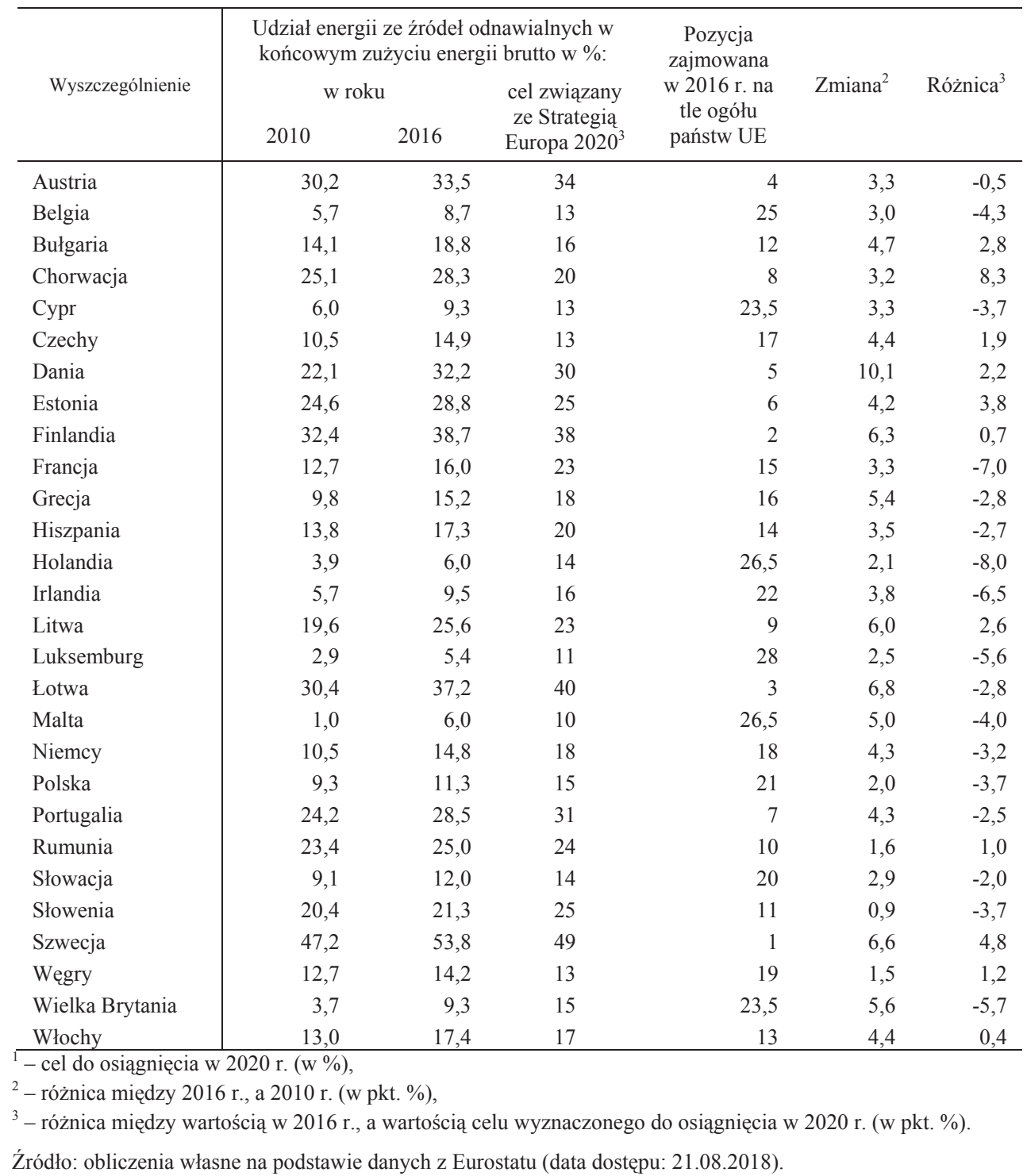


W oparciu o dane, które zostały przedstawione w tabeli 1 można stwierdzić, iż w 2016 r. największym udziałem energii ze źródeł odnawialnych w końcowym zużyciu energii brutto wśród państw członkowskich UE cechowały się następujące kraje: Szwecja $(53,8 \%)$, Finlandia (38,7\%) oraz Łotwa (37,2\%). Z kolei najmniejsza wartością omawianego udziału została odnotowana w przypadku Holandii $(6,0 \%)$, Malty $(6,0 \%)$ oraz Luksemburga $(5,4 \%)$. Zestawienie danych z Eurostatu za 2016 r. z przyjętymi krajowymi celami Strategii Europa 2020 pozwala na stwierdzenie, iż tak postawione cele wypełniło już 11 państw członkowskich. Odnosząc się do wskazanych w tabeli 1 wspomnianych docelowych wskaźników udziału energii ze źródeł odnawialnych w końcowym zużyciu energii brutto należy wskazać, iż ich wartości zostały wyznaczone na podstawie przełożenia celu wyznaczonego dla obszaru całej UE na cele krajowe przy jednoczesnym uwzględnieniu sytuacji społeczno-gospodarczej w poszczególnych państwach. Tym samym zgodnie z idea zrównoważonego rozwoju nastapiło tutaj odwołanie do zasady solidarności społecznej w wymiarze międzynarodowym.

Przytoczony powyżej wskaźnik wykorzystywany jest powszechnie przez badaczy przedmiotu do porównywania państw pod względem dążenia do zrównoważonego rozwoju w sektorze energetycznym. Niemniej jednak ciągły postęp konceptualny zachodzący w zakresie idei zrównoważonego rozwoju sprawia, iż na obecną chwilę zmienna ta zdaniem autora niniejszego artykułu jest niewystarczająca dla takich uporządkowań. W tym zakresie warto zwrócić szczególną uwagę na Agendę 2030 i jej cel 7, w którym to zdefiniowano nowe wielowymiarowe spojrzenie na problematykę sektora energetycznego (ONZ 2015). W myśl zapisów wskazanej rezolucji Organizacji Narodów Zjednoczonych, której to stroną jest również Polska, omawiany sektor należy traktować w szerszej perspektywie niż dotychczas. Stąd też przy ocenie rozwoju sektora energetycznego w zakresie postępów ukierunkowanych na zrównoważony rozwój, poza wskazywanym już wskaźnikiem, należy brać pod rozważania zmienne, które obrazują stopień zależności sektora w danym państwie od importu surowców energetycznych, czy też społeczne uwarunkowania jego funkcjonowania (możliwość nabycia przez konsumentów energii po przystępnej cenie).

Uwzględniając powyższe rozważania $\mathrm{w}$ celu skonstruowania odpowiedniego zbioru wyjściowego (potencjalnego) zestawu zmiennych wykorzystano wskaźniki sugerowane do śledzenia postępów w zakresie celu 7 Agendy 2030 przez Eurostat. Wskaźniki te uwzględniają jednocześnie wyzwania jakie zostały w omawianym obszarze postawione przez Strategię Europa 2020. Stąd też do dalszych analiz wybrano następujące zmienne:

$X_{1}$ - wskaźnik intensywność emisji gazów cieplarnianych (2000 r. $\left.=100 \%\right)$,

$\mathrm{X}_{2}$ - udział energii z odnawialnych źródeł w końcowym zużyciu energii brutto (\%),

$\mathrm{X}_{3}$ - pierwotne zużycie energii $(2005 \mathrm{r}$. $=100 \%)$,

$\mathrm{X}_{4}$ - końcowe zużycie energii $(2005 \mathrm{r}$. $=100 \%)$,

$\mathrm{X}_{5}$ - końcowe zużycie energii $\mathrm{w}$ gospodarstwach domowych na 1 mieszkańca (w kilogramach ekwiwalentu ropy naftowej),

$\mathrm{X}_{6}$ - efektywność energetyczna (euro za zużyty kilogram ekwiwalentu ropy naftowej),

$\mathrm{X}_{7}$ - wskaźnik zależności energetycznej (wyrażony jako \% energii pochodzącej z importu w całkowitym zużyciu energii),

$\mathrm{X}_{8}$ - ludność nie będąca w stanie odpowiednio ogrzać domu ze względu na ubóstwo (jako $\%$ populacji danego kraju).

Wartości powyżej wskazanych wskaźników zostały przedstawione w odniesieniu do roku 2016 (spełnione kryterium dostępności wszystkich wskazanych danych w wersji najnowszej). Analizą objęto dane dla 28 państw członkowskich UE. Źródłem danych był 
Eurostat (data dostęu: 21.08.2018). Przeprowadzona analiza formalna pozwoliła na stwierdzenie, iż wszystkie zmienne cechują się dostępnością danych dla krajów, które zostały wybrane do badania.

$\mathrm{W}$ zbiorze ośmiu wymienionych wskaźników, cechy $\mathrm{X}_{1}, \mathrm{X}_{3}, \mathrm{X}_{4}, \mathrm{X}_{5}, \mathrm{X}_{7}, \mathrm{X}_{8}$ maja charakter destymulant, pozostałe są stymulantami. Wskazany zbiór zmiennych wyjściowych został w następnym kroku poddany analizie statystycznej przy wykorzystaniu programu STATA mającej na celu określenie:

- zdolności dyskryminacyjnej wskaźników (zmienności ich względem badanych krajów),

- potencjału informacyjnego wytypowanych zmiennych (ich pojemności informacyjnej w celu wyeliminowania ryzyka przekazywania tej samej informacji o badanych krajach przez różne wskaźniki) [Panek 2009].

Dla przeprowadzenia oceny zdolności dyskryminacyjnej wykorzystano klasyczny współczynnik zmienności (1-3)

$$
V^{k}\left(x_{j}\right)=\frac{s\left(x_{j}\right)}{\bar{x}_{j}}, \quad \mathrm{j}=1,2, \ldots, \mathrm{m},
$$

gdzie:

$\bar{x}_{j}$ - średnia arytmetyczna wartości j-tej zmiennej, przy czym:

$$
\bar{x}_{j}=\frac{\sum_{i=1}^{n} x_{i j}}{n}
$$

$S\left(x_{j}\right)$ - odchylenie standardowej j-tej zmiennej, przy czym:

$$
S\left(x_{j}\right)=\left[\frac{1}{n} \sum_{i=1}^{n}\left(x_{i j}-\bar{x}_{j}\right)^{2}\right]^{-\frac{1}{2}}
$$

Stwierdzenie zbyt małego zróżnicowania danej zmiennej skutkowało eliminacją jej ze zbioru zmiennych diagnostycznych (4). W przeprowadzonym badaniu dochodziło do takiej sytuacji, kiedy wartość progowa zmiennej $\varepsilon<0,1$. W takim przypadku zachodziła następująca relacja:

$$
V\left(x_{j}\right) \leq \varepsilon, \quad \mathrm{j}=1,2, \ldots, \mathrm{m},
$$

Ze względu na otrzymaną wartość współczynnika zmienności z dalszego toku analiz zostały wykluczone zmienne: $\mathrm{X}_{3}, \mathrm{X}_{4}$ (tabela 2 ).

Tabela 2. Współczynnik zmienności zmiennych diagnostycznych użytych do badania

Table 2. The coefficient of variation diagnostic variables used in the study

\begin{tabular}{c|cccccccc}
\hline Zmienna & $\mathrm{X}_{1}$ & $\mathrm{X}_{2}$ & $\mathrm{X}_{3}$ & $\mathrm{X}_{4}$ & $\mathrm{X}_{5}$ & $\mathrm{X}_{6}$ & $\mathrm{X}_{7}$ & $\mathrm{X}_{8}$ \\
\hline $\begin{array}{c}\text { Współczynnik } \\
\text { zmienności }\end{array}$ & 0,108 & 0,59 & 0,094 & 0,098 & 0,33 & 0,463 & 0,442 & 0,978 \\
\hline
\end{tabular}

Źródło: obliczenia własne w programie STATA na podstawie danych z Eurostatu (data dostępu: 21.08.2018). 
Po określeniu zdolności dyskryminacyjnej wskaźników pozostałe w badaniu zmienne poddano ocenie ukierunkowanej na określenie ich potencjału informacyjnego. W tym celu zastosowano metode parametryczną Hellwiga dla której ustalono wartość progową współczynnika korelacji $\mathrm{r}^{*}$ (powyżej takiej wartości przyjmuje się, iż zmienne są ze sobą istotnie skorelowane). Autor wykorzystał w tym celu metodę minimaksową (5).

$$
r^{*}=\min _{j} \max _{j^{\prime}}\left|r_{j j^{\prime}}\right|, \quad \mathrm{j}, \mathrm{j}^{\prime}=1,2, \ldots, \mathrm{m},
$$

gdzie:

$r_{j j^{\prime}}$ - współczynnik korelacji pomiędzy $\mathrm{j}$-tą $\mathrm{i} \mathrm{j}^{\prime}$-tą dopuszczalnymi zmiennymi diagnostycznymi.

Wartość krytyczna współczynnika korelacji obliczona metodą minimaksową wyniosła 0,365. Przy wykorzystaniu metody parametrycznej wytypowano z wyjściowego zbioru wskaźników trzy zmienne reprezentanty (tabela 3). Były to dwie zmienne centralne (zmienne charakteryzujące się tym, iż są według przyjętego założenia istotnie skorelowane $\mathrm{z}$ innymi zmiennymi $\mathrm{w}$ badanym zbiorze, a przez to eliminują $\mathrm{z}$ dalszego badania zmienne względem ich satelitarne, które powielają informację w zakresie danej kwestii) oraz jedna zmienna izolowana (zmienna charakteryzująca się najniższym stopniem skorelowania $\mathrm{z}$ pozostałymi zmiennymi w badanym zbiorze).

Tabela 3. Podsumowanie wyników metody parametrycznej Hellwiga wyodrębniania zmiennych diagnostycznych Table 3. Summary of the results of Hellwig's parametric method of extracting diagnostic variables

\begin{tabular}{c|c|c}
\hline $\begin{array}{c}\text { Zmienne } \\
\text { reprezentanty }\end{array}$ & Typ zmiennej & $\begin{array}{c}\text { Zmienne satelitarne dla } \\
\text { zmiennej centralnej }\end{array}$ \\
\hline $\mathrm{X}_{8}$ & zmienna centralna & $\mathrm{X}_{1}, \mathrm{X}_{5}$ \\
$\mathrm{X}_{7}$ & zmienna centralna & $\mathrm{X}_{2}$ \\
$\mathrm{X}_{6}$ & zmienna izolowana & - \\
\hline
\end{tabular}

Źródło: obliczenia własne w programie STATA na podstawie danych z Eurostatu (data dostępu: 21.08.2018).

W związku z wyżej przedstawionymi analizami zbiór zmiennych diagnostycznych będący podstawą konstrukcji miary syntetycznej składał się z 3 wskaźników określających rozwój w zakresie problematyki sektora energetycznego państw członkowskich UE. Wśród zmiennych znalazły się dwie destymulanty oraz jedna stymulanta. Współczynniki zmienności wytypowanych zmiennych diagnostycznych oraz zastosowanie metody parametrycznej pozwalają na stwierdzenie, iż ich wartość informacyjna jest wystarczająca dla przeprowadzenia wielowymiarowej analizy porównawczej.

\section{Transformacja zmiennych diagnostycznych}

Przeprowadzenie odpowiedniej transformacji zmiennych diagnostycznych, a więc ich wystandaryzowanie, stanowi po analizie statystycznej kolejny krok ukierunkowany na przeprowadzenie wielowymiarowej analizy porównawczej. W poruszanym artykule procedura taka, ze względu na wytypowane do badania zmienne diagnostyczne, została ukierunkowana na ujednolicenie ich charakteru. Tym samym konieczne stało się doprowadzenie zmiennych do ich wzajemnej porównywalności, zastąpienie różnych 
zakresów zmienności poszczególnych zmiennych zakresem stałym oraz wyeliminowanie z obliczeń ujemnych wartości tak opracowanych zmiennych (Grabiński, Wydymus, Zeliaś, 1989; Panek, Zwierzchowski, 2013). Ze względu na wskazane założenia co do charakteru dalszego opracowania zbioru zmiennych diagnostycznych, w pierwszej kolejności przeprowadzono stymulację zmiennych. Polegała ona na przekształceniu ilorazowym destymulant w stymulanty (6).

$$
x_{i j}^{S}=b-\left[x_{i j}^{D}\right]^{-1}, i=1,2, \ldots, n ; j=1,2, \ldots, m ; b>0,
$$

gdzie:

$x_{i j}^{S}$ - wartość j-tej zmiennej po przekształceniu w stymulantę w i-tym obiekcie,

$x_{i j}^{D}$ - wartość j-tej zmiennej destymulanty w i-tym obiekcie,

$\mathrm{b}$ - stała przyjmowana w sposób arbitralny (w przeprowadzonej analizie $\mathrm{b}=1$ ).

Przeprowadzona stymulacja zmiennych $\mathrm{X}_{7}$ oraz $\mathrm{X}_{8}$ przyczyniła się do ujednolicenia zbioru zmiennych diagnostycznych pod względem ich preferencji. Efektem przeprowadzenia wskazanej procedury było uzyskanie zbioru zmiennych diagnostycznych, który charakteryzował się następującą zależnością - im wskaźnik liczbowy opisujący daną zmienną był wyższy tym jego wartość przyczyniała się do korzystniejszej oceny danego państwa pod względem badanej kwestii.

Następnie ze względu na to, iż wybrane do badań zmienne charakteryzowały się różnymi jednostkami miar przeprowadzono normalizację zakresu zmienności dla wszystkich zmiennych diagnostycznych. W tym celu zostało zastosowane przekształcenie normalizacyjne w oparciu o klasyczną standaryzację (7). Wybór tej formuły normalizacyjnej podyktowany był przyjęciem, iż państwa UE-28 zostaną porównane między sobą $\mathrm{w}$ zakresie badanego przedmiotu w oparciu o metodę wzorca rozwoju $\mathrm{Z}$. Hellwiga.

$$
z_{i j}=\frac{x_{i j}-\bar{x}_{j}}{S\left(x_{j}\right)}, i=1,2, \ldots, n ; j=1,2, \ldots, m
$$

gdzie: $z_{i j}$-znormalizowana wartość j-tej zmiennej w i-tym obiekcie.

Znormalizowane zmienne $\mathrm{w}$ ostatnim kroku transformacji poddano procedurze wyeliminowania ujemnych wartości zmiennych (8). Dzięki stałej $\varepsilon$ (9), która powodowała przesunięcie na skali w górę wartości wszystkich zmiennych o jednakową wielkość została zachowana wzajemna relacja między badanymi zmiennymi.

$$
z_{i j}=\left\{\begin{array}{l}
z_{i j} \quad g d y \min _{i, j}\left\{z_{i j}\right\}>0 \\
z_{i j}+\varepsilon g d y \min _{i, j}\left\{z_{i j}\right\} \leq 0
\end{array}, \mathrm{i}=1,2, \ldots, \mathrm{n} ; \mathrm{j}=1,2, \ldots, \mathrm{m},\right.
$$

przy czym:

$$
\varepsilon=-\min _{i, j}\left\{z_{i j}\right\}+\frac{1}{5} S(z),
$$

gdzie: $S(z)$ - odchylenie standardowe obliczone ze wszystkich elementów macierzy znormalizowanych danych wejściowych. 
Przeprowadzona w wyżej opisany sposób transformacja zmiennych diagnostycznych przyczyniła się do odpowiedniego ich wystandaryzowania.

\section{Badanie właściwe}

Dla realizacji przyjętego celu badania, jakim było uporządkowanie państw członkowskich UE-28 pod względem opisywanej sytuacji dotyczącej sektora energetycznego wybrano metodę wzorca rozwoju Z. Hellwiga. Jest to jedna z metod porządkowania liniowego, która poza ustaleniem hierarchii obiektów umożliwia ich porównanie w oparciu o wyznaczony wzorzec. W przeprowadzonym badaniu ze względu na to, iż podczas transformacji zmiennych destymulanty zamieniono $\mathrm{w}$ stymulanty, współrzędne obiektu wzorcowego zostały wyznaczone przy wykorzystaniu następującego wzoru:

$$
z_{0 j}=\max \left\{z_{i j}\right\}, i=1,2, \ldots, n ; j=1,2, \ldots, m .
$$

Tym samym wzorzec dla danego wskaźnika stanowiło państwo UE o najwyższej zaobserwowanej wartości badanej zmiennej, a więc o najbardziej korzystniej sytuacji. Następnie dla każdego z państw obliczono jego odległość od obiektu wzorcowego (11):

$$
s_{i}=1-\frac{d_{i 0}}{d_{0}}, i=1,2, \ldots, n
$$

przy czym:

$$
\begin{gathered}
d_{i 0}=\sqrt{\sum_{j=1}^{m}\left(z_{i j}-z_{0 j}\right)^{2},} \\
d_{0}=\bar{d}_{0}+2 S\left(d_{0}\right), \\
\bar{d}_{0}=n^{-1} \sum_{i=1}^{n} d_{i 0}, \\
S\left(d_{0}\right)=\sqrt{n^{-1} \sum_{i=1}^{n}\left(d_{i 0}-\bar{d}_{0}\right)^{2}},
\end{gathered}
$$

gdzie:

$s_{i}$ - wartość miernika syntetycznego obliczona metodą wzorca rozwoju Hellwiga, $\bar{d}_{0}-$ średnia arytmetyczna cechy (wskaźnika syntetycznego) $d_{0}$,

$S\left(d_{0}\right)$ - odchylenie standardowe cechy $d_{0}$.

W tabeli 4 zostały zaprezentowane wyniki porządkowania państw członkowskich UE pod względem poziomu rozwoju sektora energetycznego rozumianego przez pryzmat wyzwań zrównoważonego rozwoju otrzymane za pomocą metody wzorca rozwoju Z. Hellwiga. Poszczególne kraje zostały uporządkowane od najbardziej do najmniej rozwiniętych pod względem analizowanej w badaniu kwestii. W tak otrzymanym rankingu 
państw członkowskich UE czołowe miejsca zajęły Dania, Estonia oraz Szwecja. Ostatnie miejsce w prezentowanym zestawieniu zajęła Bułgaria.

Uzyskane i zaprezentowane w tabeli 3 wyniki w następnej kolejności poddano procedurze grupowania, której celem było określenie sytuacji danego państwa na tle pozostałych pod względem rozwoju sektora energetycznego w myśl idei zrównoważonego rozwoju. Wyodrębniono trzy kategorie takiej sytuacji:

- $\quad$ korzystna (wysoki poziom rozwoju),

- przeciętna (średni poziom rozwoju),

- $\quad$ niekorzystna (niski poziom rozwoju).

Tabela 4. Wyniki porządkowania państw członkowskich UE pod względem zdefiniowanego w badaniu poziomu rozwoju sektora energetycznego otrzymane metodą wzorca rozwoju Z. Hellwiga

Table 4. The results of the ordering of EU member states in terms of the level of development of the energy sector defined in the study, obtained by the method of development of Z. Hellwig

\begin{tabular}{l|c|c}
\hline \multicolumn{1}{c|}{ Kraj } & Wartość zmiennej syntetycznej & Zajmowana pozycja \\
\hline Dania & 0,585 & 1 \\
Estonia & 0,445 & 2 \\
Szwecja & 0,331 & 3 \\
Luksemburg & 0,300 & 4 \\
Holandia & 0,292 & 5 \\
Wielka Brytania & 0,285 & 6 \\
Austria & 0,276 & 7 \\
Irlandia & 0,266 & 8 \\
Finlandia & 0,253 & 9 \\
Niemcy & 0,245 & 10 \\
Francja & 0,237 & 11 \\
Malta & 0,216 & 12 \\
Czechy & 0,210 & 13 \\
Rumunia & 0,198 & 14 \\
Słowenia & 0,187 & 15 \\
Belgia & 0,180 & 16,5 \\
Polska & 0,180 & 16,5 \\
Hiszpania & 0,178 & 18 \\
Włochy & 0,173 & 19 \\
Słowacja & 0,153 & 20 \\
Chorwacja & 0,148 & 21 \\
Lotwa & 0,134 & 22 \\
Portugalia & 0,132 & 23 \\
Grecja & 0,129 & 24 \\
Cypr & 0,118 & 25 \\
Węgry & 0,117 & 26 \\
Litwa & 0,081 & 27 \\
Bułgaria & 0,073 & 28 \\
\hline Zródło: obliczenia własne w programie STATA na podstawie danych z Eurostatu (data dostępu: 21.08.2018). \\
\end{tabular}


W celu przyporządkowania danego państwa do wskazanych kategorii posłużono się metodą klas naturalnych przerw (klasy Jenksa). Metoda ta umożliwia pogrupowanie obiektów o podobnych wartościach otrzymanych w badaniu, przy jednoczesnej maksymalizacji różnic występujących między klasami. Wyniki grupowania prezentuje rysunek 1.

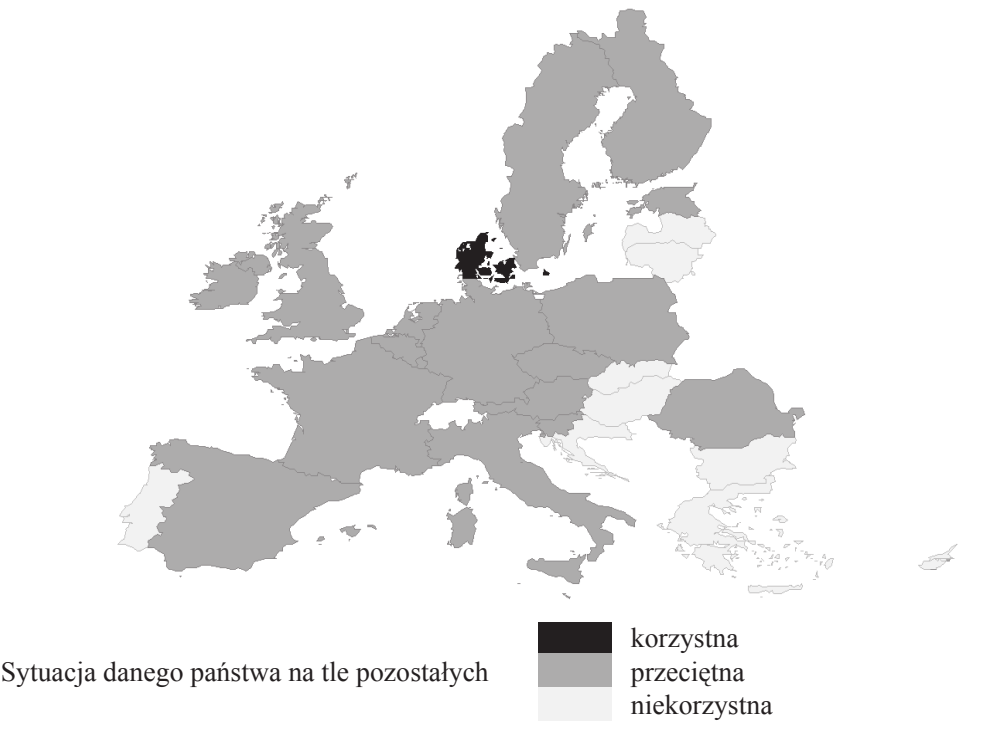

Rys. 1. Grupowanie krajów UE pod względem oceny dotyczącej sytuacji rozwoju sektora energetycznego w myśl idei zrównoważonego rozwoju przy pomocy metody naturalnych przerw (klasy Jenksa)

Fig. 1. Grouping of EU countries in terms of the assessment of the development situation of the energy sector in accordance with the idea of sustainable development using the natural breaks method (Jenks)

Źródło: Opracowanie własne w programie GeoDa na podstawie wyników wielowymiarowej analizy porównawczej danych z Eurostatu (data dostępu: 21.08.2018).

Syntetyczna ocena poziomu rozwoju sektora energetycznego w myśl idei zrównoważonego rozwoju i jej klasyfikacja metodą naturalnych przerw Jenksa wskazuje, że 64\% spośród państw członkowskich UE osiąga przeciętną ocenę w tym zakresie na tle ogółu. Należy przy tym zauważyć, iż niemalże $1 / 3$ państw charakteryzuje się sytuacją niekorzystną. W ich przypadku oznacza to, iż prowadzona dotychczas polityka energetyczna, a zwłaszcza jej elementy ukierunkowane na budowanie dostępu do źródeł stabilnej, zrównoważonej i nowoczesnej energii po przystępnej cenie są niewystarczające i w znaczącym stopniu odstają od lidera w tym zakresie, czyli Danii. Polska znalazła się w gronie państw o przeciętnej sytuacji.

Miarą statystyczną, która pozwala na ocenę zgodności uzyskanych podczas przeprowadzonej wielowymiarowej analizy porównawczej uporządkowań z klasycznym wskaźnikiem porządkującym państwa członkowskie UE pod względem udziału energii ze źródeł odnawialnych w końcowym zużyciu energii brutto jest współczynnik korelacji rang Spearmana (16). Współczynnik ten przyjmuje wartość z przedziału $<-1,1>$, a jego znak informuje o charakterze uporządkowań (dodatni - uporządkowanie zgodne; ujemny - 
uporządkowanie niezgodne). Zgodność uporządkowania jest tym większa, im współczynnik korelacji rang Spearmana jest bliższy jedności.

$$
r_{s}=1-\frac{6 * \sum d_{i}^{2}}{n\left(n^{2}-1\right)}
$$

gdzie:

$d_{i}$ - różnice między rangami zmiennych syntetycznych, $\mathrm{n}$ - liczba obiektów.

Otrzymana według klasyfikacji współzależności J. Guilford'a nikła wartość współczynnika korelacji rang Spearmana $(0,015)$ wskazuje, iż użyte w badaniu zmienne przyczyniają się do stworzenia nowego uporządkowania państw członkowskich pod względem badanego zjawiska, niż to ma miejsce w klasycznym zestawieniu (tabela 1). Fakt ten świadczy również o tym, iż wskaźnik określający udział energii ze źródeł odnawialnych w końcowym zużyciu energii brutto nie odzwierciedla współczesnego rozumienia rozwoju sektora energetycznego w myśl koncepcji zrównoważonego rozwoju zaproponowanego w Agendzie 2030.

\section{Podsumowanie}

Przeprowadzone badania zobrazowały, iż na sektor energetyczny należy patrzeć nie tylko przez pryzmat wskaźników ekonomicznych, ale i tych, które uwzględniają cele środowiskowe oraz społeczne. Omawiana problematyka w takim ujęciu jest coraz szerzej poruszana na arenie międzynarodowej w zakresie idei zrównoważonego rozwoju. W sposób szczególny aspekt ten dostrzegalny jest w UE, gdzie oprócz obecnie obowiązującej Strategii Europa 2020 poszczególne państwa stały się stroną wielu międzynarodowych porozumień mających na celu bardziej zrównoważony niż dotychczas rozwój. Wśród nich istotne miejsce zajmuje Agenda 2030.

Rozwój sektora energetycznego opisywany jest przez badaczy przedmiotu przez coraz to większą liczbę zmiennych. Stąd też nie sposób obecnie omawiać tego aspektu wyłącznie przez pryzmat klasycznego ujęcia jakim jest produkcja energii z odnawialnych źródeł i jej udziału w końcowym zużyciu energii brutto. Wskaźnik ten nie odzwierciedla współczesnego znaczenia obszarowego idei zrównoważonego rozwoju w sektorze energetycznym (jak wykazały badania charakteryzuje się nikłym stopniem skorelowania z otrzymanym w badaniu uporządkowaniem).

Sporządzone w wyniku przeprowadzonych analiz uporządkowanie państw członkowskich UE i ich pogrupowanie w wyniku przyjętej kategoryzacji pozwalają na wskazanie państw do których obecnie w sposób szczególnych należałoby skierować pomoc ukierunkowaną zarówno na merytoryczne, jak i finansowe wsparcie pozwalające na budowę odpowiedniej jakości sektora energetycznego. Wśród wskazanych państw znalazły się Słowacja, Chorwacja, Łotwa, Portugalia, Grecja, Cypr, Węgry, Litwa oraz Bułgaria. Ludność zamieszkująca te kraje w związku z przeprowadzoną oceną może być narażona na wykluczenie energetyczne spowodowane jakością dostarczanej energii, jej dostępem oraz ceną. Tym samym wsparcie zewnętrzne ukierunkowane na rozwój energetyki odnawialnej w tych krajach może przyczynić się do znaczącej poprawy sytuacji (w szczególności w obszarze związanym z dywersyfikacją źródeł energii). Zaproponowany w artykule 
zestaw zmiennych użytych do oceny sytuacji sektora energetycznego w kontekście idei zrównoważonego rozwoju może stanowić wskazówkę przy konstruowaniu tego rodzaju zestawień.

\section{Literatura}

Belz, F.M., Binder, J.K. (2017). Sustainable entrepreneurship: A convergent process model. Business Strategy and the Environment, 26(1), 1-17.

Davies, P.G. (2017). European Union Environmental Law: An introduction to key selected issues. Routledge, New York.

Dyllick, T., Muff, K. (2016). Clarifying the meaning of sustainable business: Introducing a typology from business-as-usual to true business sustainability. Organization and Environment, 29(2), 156-174.

Europa 2020. Strategia na rzecz inteligentnego i zrównoważonego rozwoju sprzyjającego włączeniu społecznemu (Europe 2020: the European Union strategy for growth and employment), KOM(2010) 2020 final. Pobrane 10 sierpnia $2018 \mathrm{z}$ : http://eurlex.europa.eu.

Eurostat, www.eurostat.eu. Pobrane 21 sierpnia $2018 \mathrm{r}$

Gasparatos, A., Doll, C.N., Esteban, M., Ahmed, A., Olang, T.A. (2017). Renewable energy and biodiversity: Implications for transitioning to a Green Economy. Renewable and Sustainable Energy Reviews, 70, 161184.

Gielnik, A., Rosicki, R. (2013). Energetyka wiatrowa w Polsce - możliwości rozwoju i zagrożenia (Wind energy in Poland - development opportunities and threats). W: Kwiatkiewicz P. (red.). Bezpieczeństwo energetyczne - surowce kopalne vs alternatywne źródła energii (Energy security - fossil raw materials vs. alternative energy sources), WSB, Poznań

Grabiński, T., Wydymus, S., Zeliaś, A. (1989). Metody taksonomii numerycznej w modelowaniu zjawisk społeczno-gospodarczych (Methods of numerical taxonomy in modelling socio-economic phenomena), PWN, Warszawa.

Kryk, B. (2013). Zrównoważona jakość życia a zrównoważona konsumpcja i zachowania ekologiczne polskich konsumentów (Sustainable quality of life vs sustainable consumption and environmental consumer behaviour). Handel Wewnętrzny, 6A(2), 5-19.

Loiseau, E., Saikku, L., Antikainen, R., Droste, N., Hansjürgens, B., Pitkänen, K., Leskinen, P., Kuikman, P., Thomsen, M. (2016). Green economy and related concepts: An overview. Journal of Cleaner Production, $139,361-371$

McAfee, K. (2016). Green economy and carbon markets for conservation and development: a critical view. International Environmental Agreements: Politics, Law and Economics, 16(3), 333-353.

Omer, A.M. (2017). Sustainable development and environmentally friendly energy systems. International Journal of Physical Sciences and Engineering, 1(1), 1-39.

ONZ (2015). Przekształcamy nasz świat: Agenda na rzecz zrównoważonego rozwoju 2030 (Transforming our world: the 2030 Agenda for Sustainable Development). A/RES/70. http://www.unic.un.org.pl/ files/164/Agenda\%202030_pl_2016_ostateczna.pdf. Pobrane 23 sierpnia 2018 r.

ONZ (1987). Report of the World Commission on Environment and Development: Our Common Future, Pobrane 8 sierpnia $2018 \mathrm{z}$ : http://www.un-documents.net/our-common-future.pdf.

Pająk, K., Dahlke, P., Kvilinskyi, O. (2016). Determinanty rozwoju regionalnego - współczesne odniesienie (Determinants of the regional development - contemporary reference). Roczniki Ekonomiczne KujawskoPomorskiej Szkoty Wyższej w Bydgoszczy, (9), 109-122.

Panek, T. (2009). Statystyczne metody wielowymiarowej analizy porównawczej (Statistical methods of multivariate comparative analysis). Szkoła Główna Handlowa, Warszawa.

Panek, T., Zwierzchowski, J. (2013). Statystyczne metody wielowymiarowej analizy porównawczej. Teoria i zastosowanie (Statistical methods of multivariate comparative analysis. Theory and application). Szkoła Główna Handlowa, Warszawa.

Pultowicz, A. (2009). Przesłanki rozwoju rynku odnawialnych źródeł energii w Polsce w świetle idei zrównoważonego rozwoju (The premises of renewable energy sources market development in Poland in the light of sustainable development Idea). Problemy Ekorozwoju, 4(1), 109-115.

SRU (German Advisory Council on the Environment) (2012) Environmental Report 2012. Responsibility in a finite world. Chapter 11: Respecting environmental limits: a challenge for policy strategies, Berlin.

Sulich, A., Zema, T. (2018). Green jobs, a new measure of public management and sustainable development. European Journal of Environmental Sciences, 8(1), 69-75. 
Świerszcz, K., Grenda, B. (2018). Poziom ubóstwa energetycznego w wybranych regionach kraju jako miernik poziomu bezpieczeństwa energetycznego w wymiarze społecznym (The level of energy poverty in selected regions of the country as a measure of the level of energy security in the social dimension). Przedsiębiorczość i Zarzqdzanie, 19(2) cz. 3, 211-230.

Szczerbowski, R. (2013). Bezpieczeństwo energetyczne Polski-mix energetyczny i efektywność energetyczna (Energy security of Poland - energy mix and energy efficiency). Polityka Energetyczna, 4(16), 35-46.

Zabłocki, M. (2013). Determinanty wykorzystania odnawialnych źródeł energii w Polsce (Determinants of using renewable energy sources in Poland). Technika Poszukiwań Geologicznych, Geotermia, Zrównoważony Rozwój, 2, 29-44.

Do cytowania / For citation:

Kozar Ł. (2018). Sektor energetyczny, a wyzwania zrównoważonego rozwoju - analiza przestrzennego zróżnicowania sytuacji w UE w oparciu o wybrane wskaźniki. Problemy Rolnictwa Światowego, 18(3), 173-186; DOI: 10.22630/PRS.2018.18.3.76

Kozar Ł. (2018). Energy sector and the challenges of sustainable development - analysis of spatial differentiation of the situation in the EU based on selected indicators (in Polish). Problems of World Agriculture, 18(3), 173-186; DOI: 10.22630/PRS.2018.18.3.76 